\title{
Structure and tectonic development of the Ghab basin and the Dead Sea fault system, Syria
}

\author{
GRAHAM BREW ${ }^{1}$, JACEK LUPA ${ }^{1}$, MUAWIA BARAZANGI ${ }^{1}$, TARIF SAWAF ${ }^{2,3}$, \\ ANWAR AL-IMAM ${ }^{2,4}$ \& TAREK ZAZA ${ }^{2}$ \\ ${ }^{1}$ Institute for the Study of the Continents, Cornell University, Ithaca, New York 14853, USA \\ (e-mail:brew@geology.cornell.edu) \\ ${ }^{2}$ Syrian Petroleum Company, Ministry of Petroleum and Mineral Resources, Damascus, Syria \\ ${ }^{3}$ Present address: Al-Furat Oil Company, Damascus, Syria \\ ${ }^{4}$ Present address: Syrian-Egyptian Petroleum Services Company, Damascus, Syria
}

\begin{abstract}
We examine the structure and evolution of the Ghab basin that formed on the active, yet poorly understood, northern segment of the Dead Sea transform fault system. The basin formed in PlioQuaternary time at a complex step-over zone on the fault. Subsidence occurred along cross-basin and transform-parallel faults in two asymmetric depocentres. The larger depocentre in the south of the basin is asymmetric towards the east, the margin along which most active transform displacement apparently occurs. The Syrian Coastal Ranges, located directly west of the Ghab basin, are a consequence of Late Cretaceous and Cenozoic regional compression, heavily modified by the Dead Sea fault system and Ghab basin formation. We prefer a model whereby the Dead Sea fault system in northwest Syria developed in Plio-Quaternary time, consistent with previously proposed models of two-phase Dead Sea fault system movement and Red Sea spreading.
\end{abstract}

Keywords: Dead Sea Rift, Syria, pull-apart basins, seismic methods, tectonics.

Continental transform faults, such as the San Andreas fault in California, the Alpine fault in New Zealand, the North Anatolian fault in Turkey, and the Dead Sea fault system, involve complex structural and sedimentary regimes. This complexity relates to the history of displacement along these fundamental components of the global plate tectonic framework. Our work concerns the development of structures and history of deposition along the northern segment of the Dead Sea fault system that is relatively little studied compared to the southern Dead Sea fault system (i.e., south of the Lebanese restraining bend, Fig. 1, inset). The evolution of the Dead Sea fault system remains one of the most contentious issues of eastern Mediterranean tectonics.

Our interpretation of the structure of the Ghab basin that lies along the northern Dead Sea fault system (Fig. 1) is based on seismic-reflection profiles that are published here for the first time. Our analysis, integrated with interpretations of Bouguer gravity anomalies and surface geology, shows the deep, asymmetric, double-depocentre structure of the PlioQuaternary Ghab basin. We consider this result in the context of other strike-slip basin architectures. A regional model, founded on the previous work of Hempton (1987) and Chaimov et al. (1990), shows how the evolution of the Ghab basin integrates with theories of Late Cretaceous and Cenozoic plate motions in the eastern Mediterranean. The results of this paper suggest that the Dead Sea fault system only propagated through NW Syria in Plio-Quaternary time.

\section{The Dead Sea fault system}

The Dead Sea fault system is a transform fault linking Red Sea/Gulf of Aqaba seafloor spreading to Neo-Tethyan collision in Turkey. Most researchers agree that in total c. $107 \mathrm{~km}$ of sinistral motion has taken place on the 'southern' segment of the fault, south of the Lebanese restraining bend (Fig. 1, inset) (e.g., Quennell 1984; Beydoun 1999). Many authors have suggested that the lateral motion on the Dead Sea fault system occurred during two different episodes (e.g., Quennell 1959). In this scenario there was c. $65 \mathrm{~km}$ of movement during Miocene time, with the remaining c. $42 \mathrm{~km}$ from earliest Pliocene until present.

More controversial is the amount of translation experienced by the 'northern' Dead Sea fault system in Lebanon and farther north in NW Syria. The controversy arises from limited mapping of the trace of the Dead Sea fault system, and a lack of piercing points by pre-Pliocene features, making total offset mapping in Lebanon and Syria extremely difficult (Chaimov et al. 1990). Post-mid-Miocene displacement, judged by offset of basalt and extrapolated displacement of well-dated Quaternary fans, is documented to be around 20-25 km (Quennell 1984; Trifonov et al. 1991). Pre-Pliocene movement along the northern Dead Sea fault system is not currently documented, but cannot be entirely discounted.

Chaimov et al. (1990), expanding on the ideas of Quennell (1959), suggested that only the second episode of motion on the Dead Sea fault system (c. $42 \mathrm{~km}$ since the start of the Pliocene) has affected the northern Dead Sea fault system. In this scenario shortening in the SW Palmyride fold and thrust belt ('Palmyrides' in Fig. 1, inset) accommodated around $20 \mathrm{~km}$ of sinistral movement, leaving around $22 \mathrm{~km}$ of movement to be transferred to the Dead Sea fault system north of the Palmyrides. Approximately north-south-striking faults, that are branching from the Dead Sea fault system and continue offshore Lebanon and possibly Israel, may have translated the c. $65 \mathrm{~km}$ of pre-Pliocene displacement offshore, 


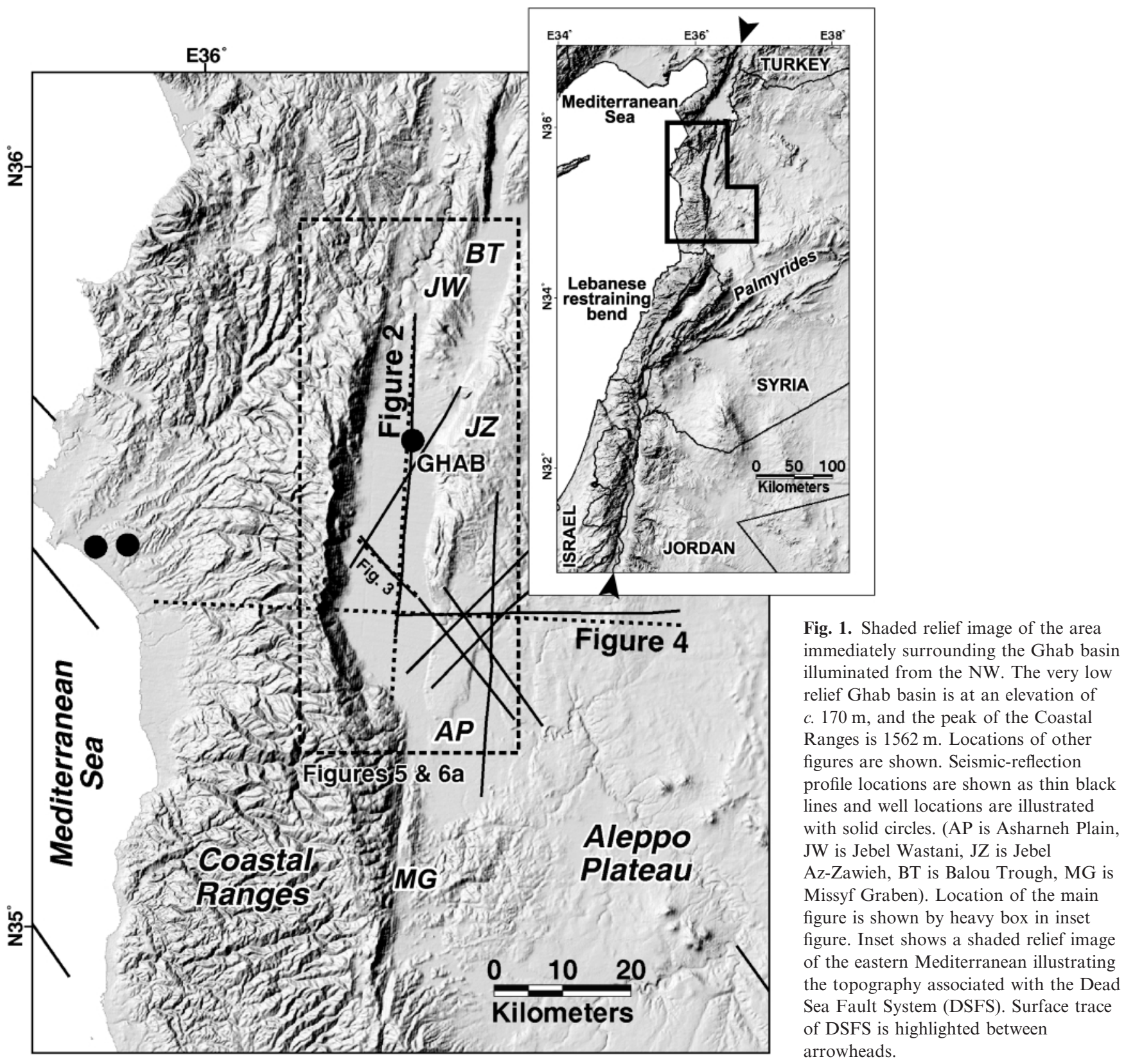

hence eliminating the requirement of pre-Pliocene slip on the northern Dead Sea fault system (Chaimov et al. 1990).

Another scenario suggests that the northern Dead Sea fault system has been inactive since the Miocene (Butler et al. 1997). However, given the geomorphological evidence for PlioceneRecent tectonic activity on the fault, together with seismicity (Ambraseys \& Jackson 1998) and GPS measurements (McClusky et al. 2000), this inactive northern fault hypothesis seems highly improbable.

The recent tectonics of the Ghab basin further attests to the current activity along the northern Dead Sea fault system. Ponikarov (1966) considered the Ghab basin to be a PlioceneRecent feature, and recognized that the basin developed on a left-step in the Dead Sea fault system. These findings were echoed in geomorphological studies by Hricko (1988), and Devyatkin et al. (1997). Palaeostress analysis on faults around the Ghab basin by Matar \& Mascle (1993) further suggest an active step-over geometry. Herein we do not present direct evidence regarding the history of movement on the northern Dead Sea fault system. However, we interpret that the Ghab basin formed as a pull-apart basin on the Dead Sea fault system since earliest Pliocene time. This supports a scenario of northern Dead Sea fault system development in which c. 20 $25 \mathrm{~km}$ of sinistral displacement has occurred on the northern Dead Sea fault system since latest Miocene-earliest Pliocene time.

\section{Data and interpretation methodology}

Among the data used for our subsurface analysis of the Ghab basin are around $260 \mathrm{~km}$ of $2 \mathrm{D}$ migrated seismic-reflection profiles (Fig. 1). The seismic sections shown here are in time, rather than depth. Within the basin seismic P-wave velocities 


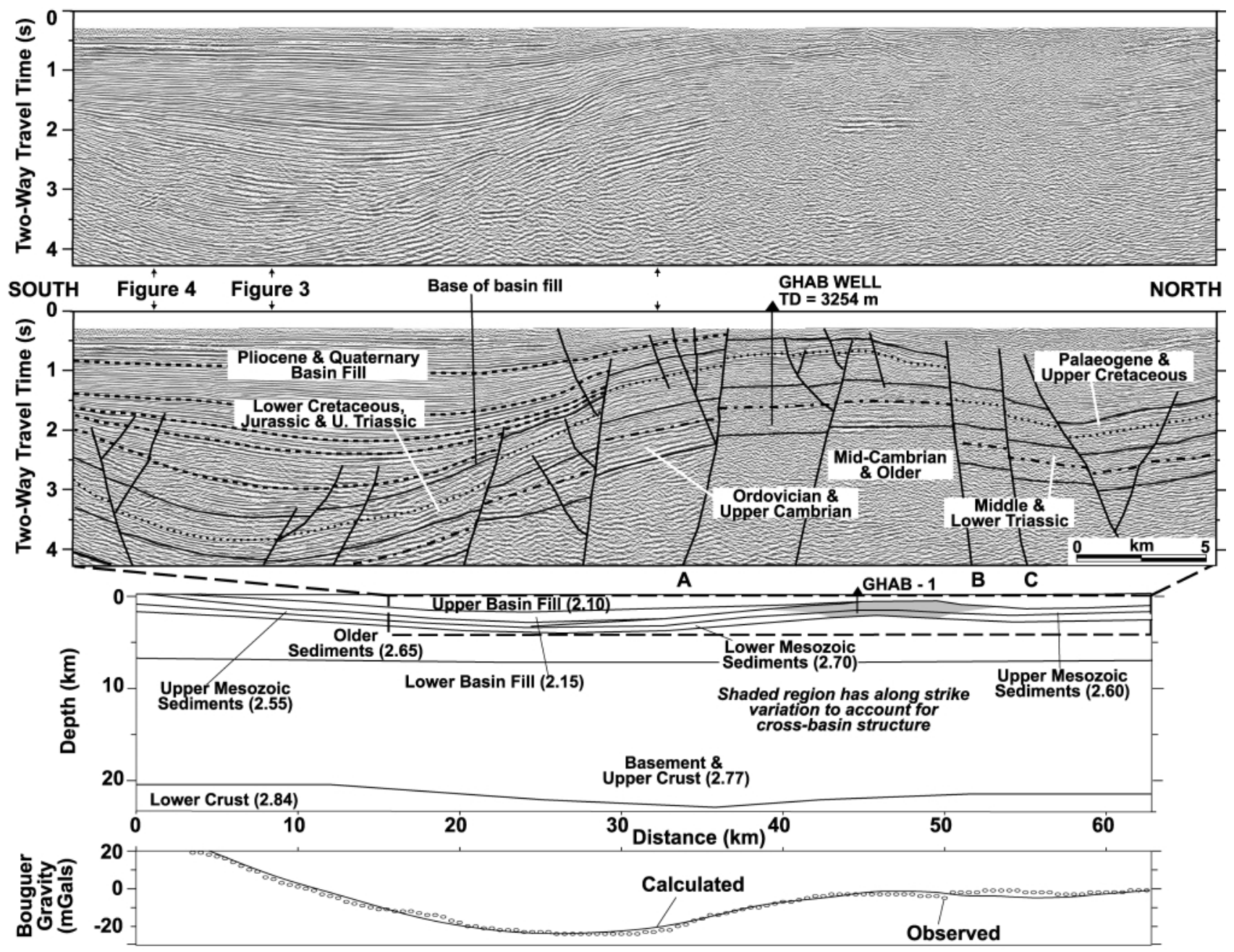

Fig. 2. Cross-section along-strike of the Ghab basin (see Fig. 1 for location) showing a seismic-reflection profile (with and without interpretation), density model and associated gravity anomalies. The dashed box on the density model illustrates the extent of seismic-reflection data coverage. Intersections with other seismic reflection profiles are shown as small arrows. Densities shown on model are $\mathrm{g} \mathrm{cm}^{-3}$. Quaternary deposits form the surface layers along the entire length of the transect. Most of the faults shown have components of both normal and strike-slip fault movement. Deeper structure cannot be constrained with current data.

are $2.0 \pm 0.2 \mathrm{~km} \mathrm{~s}^{-1}$ as derived from sonic logs and seismic stacking velocities (Dzhabur 1985). Hence the two-way time scales in Figs 2, 3, and 4 are a close approximation for depth in kilometres for the basin fill. The one deep well within the basin (Ghab, Fig. 1) was used, together with seismic signatures and shallow boring in the south of the basin (Devyatkin et al. 1997), to provide stratigraphic control on the seismic interpretations.

Geological maps and gravity interpretations provide additional information especially where seismic data were lacking. We modelled the Bouguer gravity data from a grid of eight profiles, two of which are presented here (Figs $2 \&$ 4). This modelling accounted for along-strike changes, as necessary in a narrow basin. Faults were not directly incorporated into the density models because of their insignificant effect relative to continuous surfaces. The final models give a reasonable fit ( $<3 \mathrm{mGal}$ difference) between calculated and observed anomalies. During the gravity modelling, density information came from field samples (Hricko 1988), borehole density logs, and seismic refraction data (Seber et al. 1993) and sonic logs, with velocities inverted for densities. Depth limits came from seismic refraction (Seber et al. 1993) and reflection data, and well data, as presented in this study. These densities were found to be reasonable according to our knowledge of lithologies derived from drilling information. Given these external controls on densities and depths, this gravity modelling is better determined and less ambiguous than typical gravity studies.

\section{Ghab basin}

\section{Geomorphology}

The surface expression of the Ghab basin is an extensive (roughly $60 \mathrm{~km}$ by $15 \mathrm{~km}$ ), flat plain with almost no topographic relief, thus revealing its recent lacustrine history (Fig. 1). In the south, between two strands of the Dead Sea fault system, is the Missyf graben (Fig. 1). The eastern fault strand can be traced northward at the surface along the eastern margin of the Ghab basin before bifurcating to the NNE. No definitive termination of this eastern fault is observed along the basin margin. 


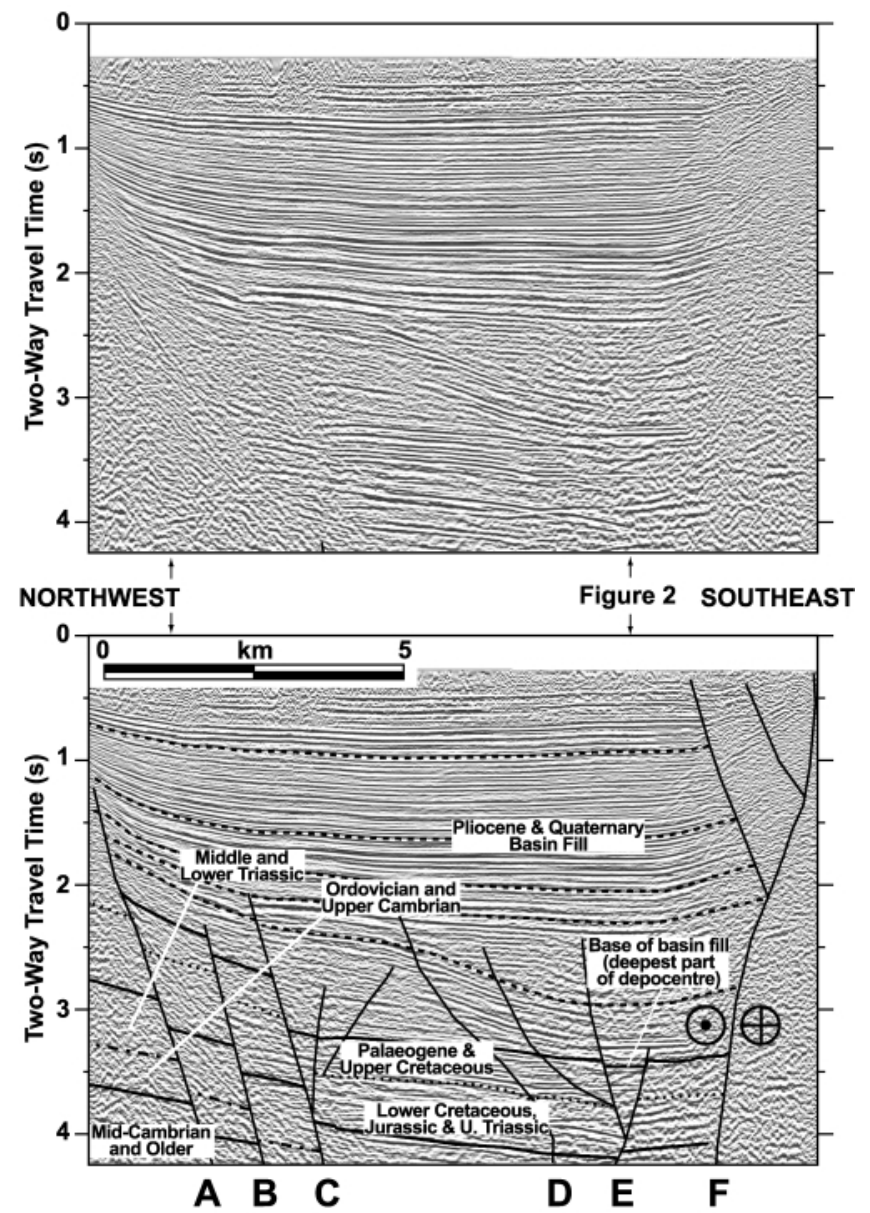

Fig. 3. Interpreted migrated seismic profile across the Ghab basin. See Fig. 1 for location. Intersections with other seismic reflection profiles are shown as small arrows. Quaternary age deposits are the surfical strata along the whole line. Most of the faults shown have components of both normal and strike-slip fault movement. The fault marked F is the main strand of the Dead Sea fault system and the major eastern bounding fault of the Ghab basin.

The Syrian Coastal Ranges; which Ponikarov (1966) referred to as Jebel An-Nusseriyeh, rise dramatically by c. $1300 \mathrm{~m}$ in just $4 \mathrm{~km}$ of distance (Fig. 1), exposing Jurassic and uppermost Triassic strata directly west of the basin. This steep flank suggests geologically recent uplift along the western margin of the Ghab basin (the origin of the Coastal Ranges is discussed below). In contrast to the eastern margin, this edge of the basin is poorly defined, obscured by significant masswasting and large blocks detached from the Coastal Ranges. Faults would be expected along the western margin given a typical fault step-over arrangement for the Ghab basin. However, no surface expression has been detected along these margins, except in the far north, probably owing to burial by mass-wasting. Surface observations indicate the Ghab basin fill is Neogene-Quaternary lacustrine and alluvial deposits, finer grained in the basin centre (Devyatkin et al. 1997).

\section{Subsurface analysis}

In our seismic interpretations (Figs 2, 3, and 4), tied to the Ghab well, the deepest mapped reflector is a relatively thin bed of Mid-Cambrian limestone. The unconformity at the top of
Palaeozoic (generally Upper Ordovician strata) presents a clear reflector where the mainly carbonate-Mesozoic section overlies a largely clastic Palaeozoic section. Middle Triassic anhydrite and dolomite form a sequence of strong reflectors, as does Lower Cretaceous sandstone. The uppermost mapped reflector, (other than arbitrarily traced horizons within the basin fill shown by dashed lines in Figs 2, 3, and 4), is at the base of basin fill that is Middle Eocene or, in the south of the basin, Upper Cretaceous (Devyatkin et al. 1997).

The Ghab well penetrates Middle Eocene limestone immediately beneath Pliocene strata. A clear unconformity at this point is expressed by abrupt facies change (clay to limestone), palaeontological evidence, and an absence of volcanic detritus that is found throughout the younger strata. We interpret this unconformity (at a depth of $350 \mathrm{~m}$ in the Ghab well, but dropping sharply to the south and north, Fig. 2) as the base of basin fill (Figs 2, 3, 4 and 5). Furthermore, we interpret a very thin layer of volcanic rocks encountered at a depth of $200 \mathrm{~m}$ within the basin fill in the Ghab well is part of a nearby 1-2 Ma old sequence.

The seismic and well data show no evidence of basin strata older than earliest Pliocene. Shallow borings $(<500 \mathrm{~m})$ in the main depocentre have also failed to penetrate rocks older than Pliocene, and find Mesozoic strata immediately below Pliocene (Devyatkin et al. 1997). Furthermore, outcrop studies have shown marine Pliocene strata at the northern end of the current Ghab basin, but continental strata of the same age near the south end of the basin (Ponikarov 1966). This indicates that the full extent of the Ghab basin topographic depression was not fully established until at least after the earliest Pliocene. Furthermore, Cenozoic volcanic activity around the Ghab basin is confined to the Plio-Quaternary (Devyatkin et al. 1997). Taking this evidence in totality, we interpret that Ghab basin formation commenced around earliest Pliocene time.

The basic structure of the Ghab basin is a fault-controlled double depocentre. The main depocentre is positioned beneath the southern portion of the surface plain, and slight northward migration of that depocentre with time is clear from the seismic data (Fig. 2). Also apparent are a mid-basin ridge (on which the Ghab well is drilled, marked $\mathrm{R}$ in Fig. 6a) and a second smaller depocentre to the north.

The relatively undeformed nature of much of the basin fill suggests that most subsidence has been accommodated along the major basin-bounding faults. An apparent western bounding fault (speculatively marked A on Fig. 3) when projected to the surface would be close to the foot of the Coastal Ranges. Abrupt sediment thickness changes are very apparent across the eastern bounding fault (marked A in Fig. 4). Most of the subsidence is clearly asymmetric in the southern depocentre controlled by the more prominent eastern basin-bounding fault (marked F in Fig. 3 ). This asymmetry is not merely a consequence of the obliquity of the seismic profile in Fig. 3. The asymmetry is also documented in the gravity modelling, and Mesozoic strata encountered by shallow drilling on the western flank (Devyatkin et al. 1997) further support this interpretation. Gravity and seismic interpretations reveal the southern depocentre to be up to c. $3400 \mathrm{~m}$ deep in the eastern part of the basin.

In the earlier stages of basin formation, accommodation space was created by movement on cross-basin faults that are now internal to the basin, rather than on the flanking faults. This displacement shifted between the faults, with older displacement on the more interior (western) faults (marked B-E in Fig. 3, marked $\mathrm{C}$ in Fig. 6a), and most recent motion 


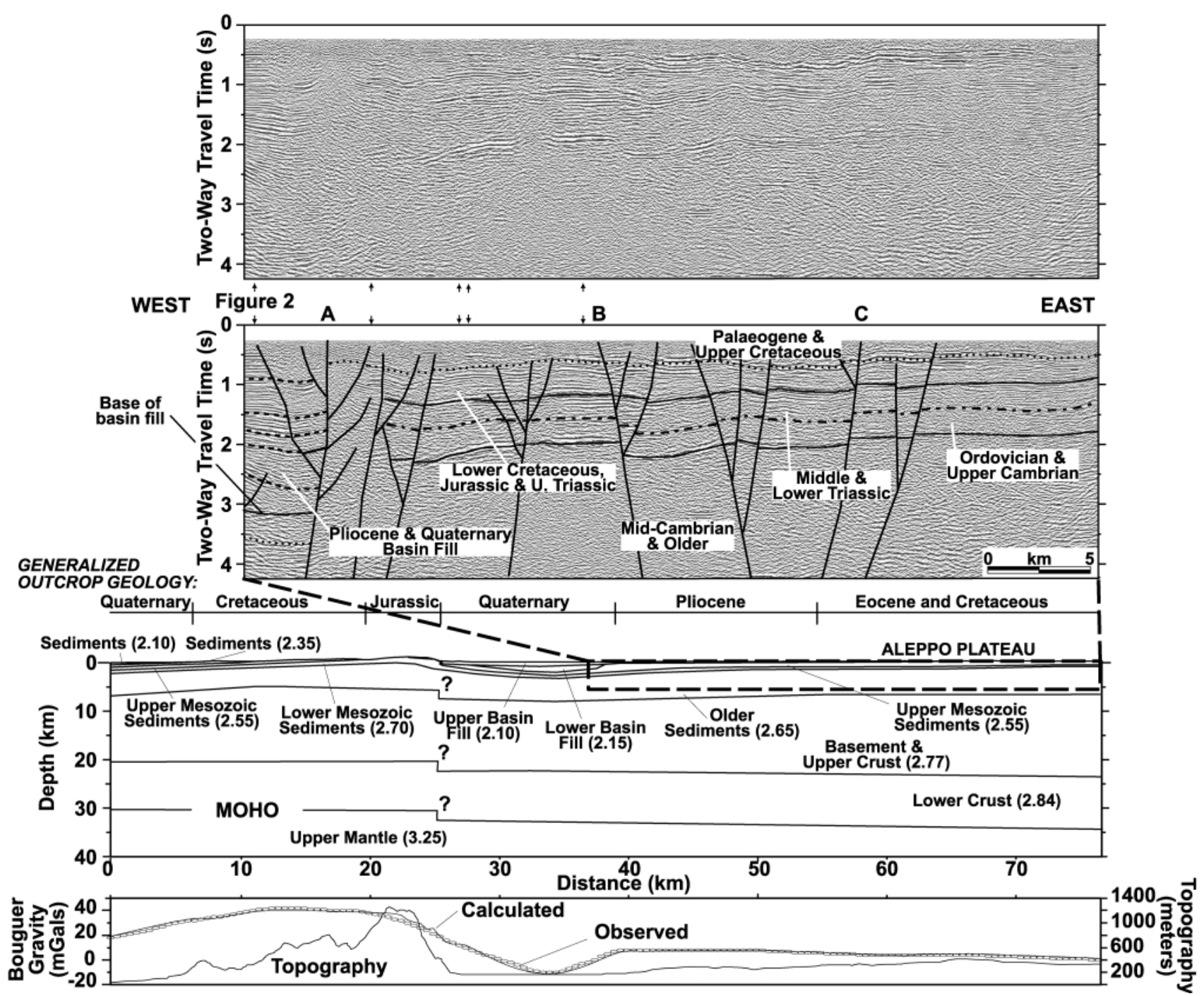

Fig. 4. Cross-section across the Ghab basin (see Fig. 1 for location) showing a seismic-reflection profile, density model and corresponding gravity anomalies along the transect. The dashed box on the density model illustrates the extent of seismic-reflection data coverage. Intersections

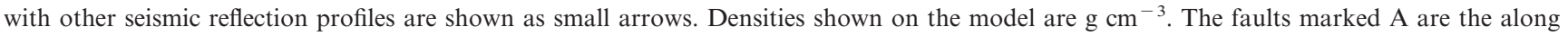
strike continuation of the main strand of the Dead Sea fault system (as shown in Fig. 5). The faults marked B and C have surface expression, as documented by Ponikarov (1966). Most of the faults shown have components of both normal and strike-slip fault movement. Note that the required thinning of the crust toward the Mediterranean Sea, although the exact lower crustal structure is not determinable. The step shown in the Moho is speculative and not resolvable in the gravity data.

accommodated on the eastern basin-bounding fault (marked F in Fig. 3).

The geometry of the faults can be appreciated from Figs 5 and 6a. Two depocentres are illustrated, the larger in the south, and the smaller in the north, both formed against the basin-bounding faults. Cross-basin faults (C in Fig. 6a) are found particularly in the south of the basin, predominately steeply dipping to the NE (faults B-E on Fig. 3). These transverse features are generally NE-SE striking and suggest some extension across the basin. The central region is dominated by acutely striking cross-basin faults that bound a horst extending across the basin (faults $\mathrm{A}-\mathrm{C}$ on Fig. 2, feature marked R in Fig. 6a). A second depocentre in the NW of the basin (Figs $2 \& 5$ ) is somewhat asymmetric toward the western bounding fault and is up to $c .1700 \mathrm{~m}$ deep.

NNE of the Ghab basin, faults splay out significantly and several depocentres are present. Our gravity interpretations and previous work (Hricko 1988) report $500-1000 \mathrm{~m}$ of basin fill in what is apparently another strike-slip basin bounded by recently active left-lateral faults beneath the Balou Trough (Figs $1 \& 5$ ).

East of the south part of the Ghab basin, (Asharneh Plain, Fig. 1), there is no significant Bouguer gravity low and seismic interpretations also indicate that there is no significant basin in that area (Fig. 4). Apparent strike-slip faults in the Aleppo plateau area are relatively minor and accommodate only small amounts of translation (Fig. 4). Seismic images of the major Dead Sea fault system deformation (labelled A on Fig. 4) correspond directly with surface faults inferred from topographic imagery (Fig. 5) and Quaternary faults observed in the field. The displacement is distributed among several fault strands that are seen to coalesce at depth. This image is comparable with other examples of continental transform faults (e.g., Ben-Avraham 1992), and is a typical negative 


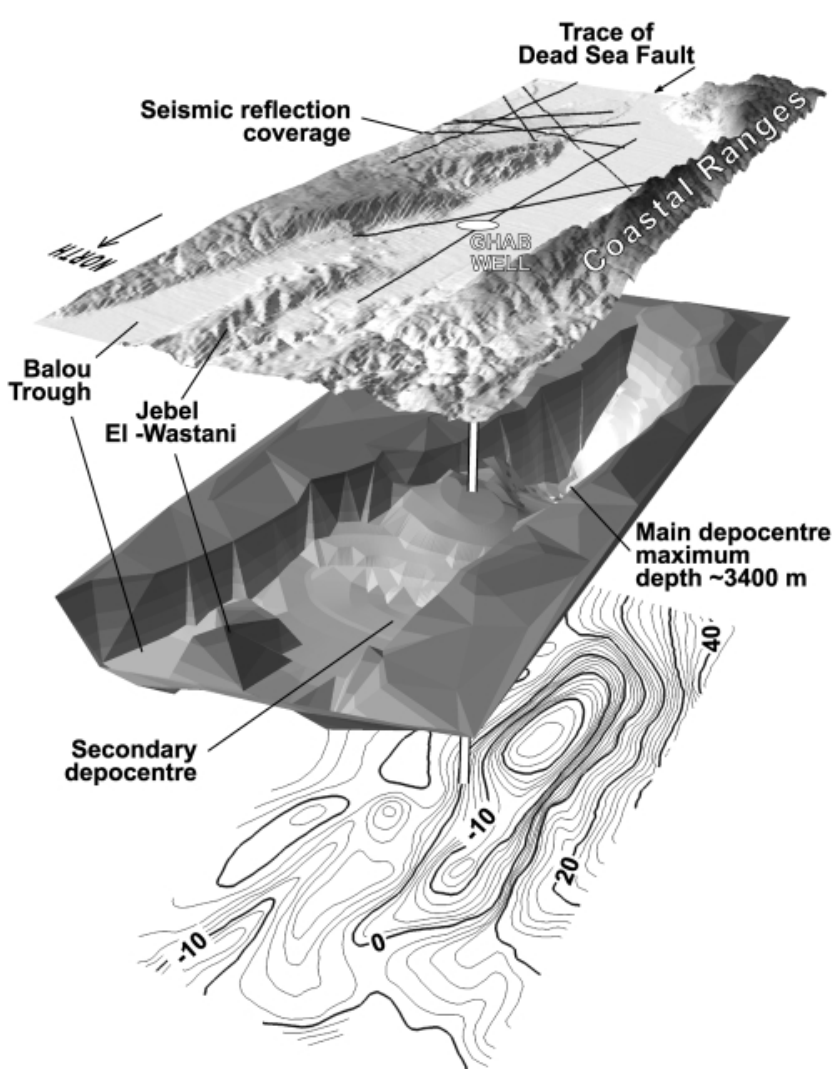

Fig. 5. Perspective view from the NW of the Ghab basin, looking to the SE. See Fig. 1 for location. The top layer represents the topography surrounding the Ghab basin. The middle layer is a representation of the base of Ghab basin sedimentary fill; the slightly angular appearance is a consequence of the gridding process. The lowermost layer shows Bouguer gravity contours. Contour interval is $2 \mathrm{mGal}$, bolder lines every $10 \mathrm{mGal}$.

flower structure (tulip) typically shown to be associated with strike-slip faulting in an extensional setting.

\section{Comparison with other basins and basin models}

As suggested by Matar \& Mascle (1993), the Ghab basin is generally representative of a transtensional pull-part basin. In this section, we examine some of the second-order features of the basin. Asymmetric basins have been documented along the Dead Sea fault system (especially in the Gulf of Aqaba), the San Andreas Fault, the North Anatolian fault, and many other major strike-slip faults (Ben-Avraham 1992; Ben-Avraham \& Zoback 1992). These asymmetric basins are bound on only one side by a major linear strike-slip fault, against which most deposition generally occurs. The opposite side of the basin is bound by predominantly normal faults; thus, the overall fault geometry is distinctly different from the classic step-over. The sense of basin asymmetry commonly changes along strike in these fault systems as strike-slip displacement transfers from one en-echelon strike-slip fault to the next. This geometry could be caused by a reorientation of stresses near a weak fault in an otherwise strong crust, so as to minimize shear stress on the fault, resulting in transform-normal extension (Ben-Avraham \& Zoback 1992).

The asymmetry within the Ghab basin closely follows this pattern of deformation, with the southern depocentre asymmetric to the east. This suggests that at the latitude of the
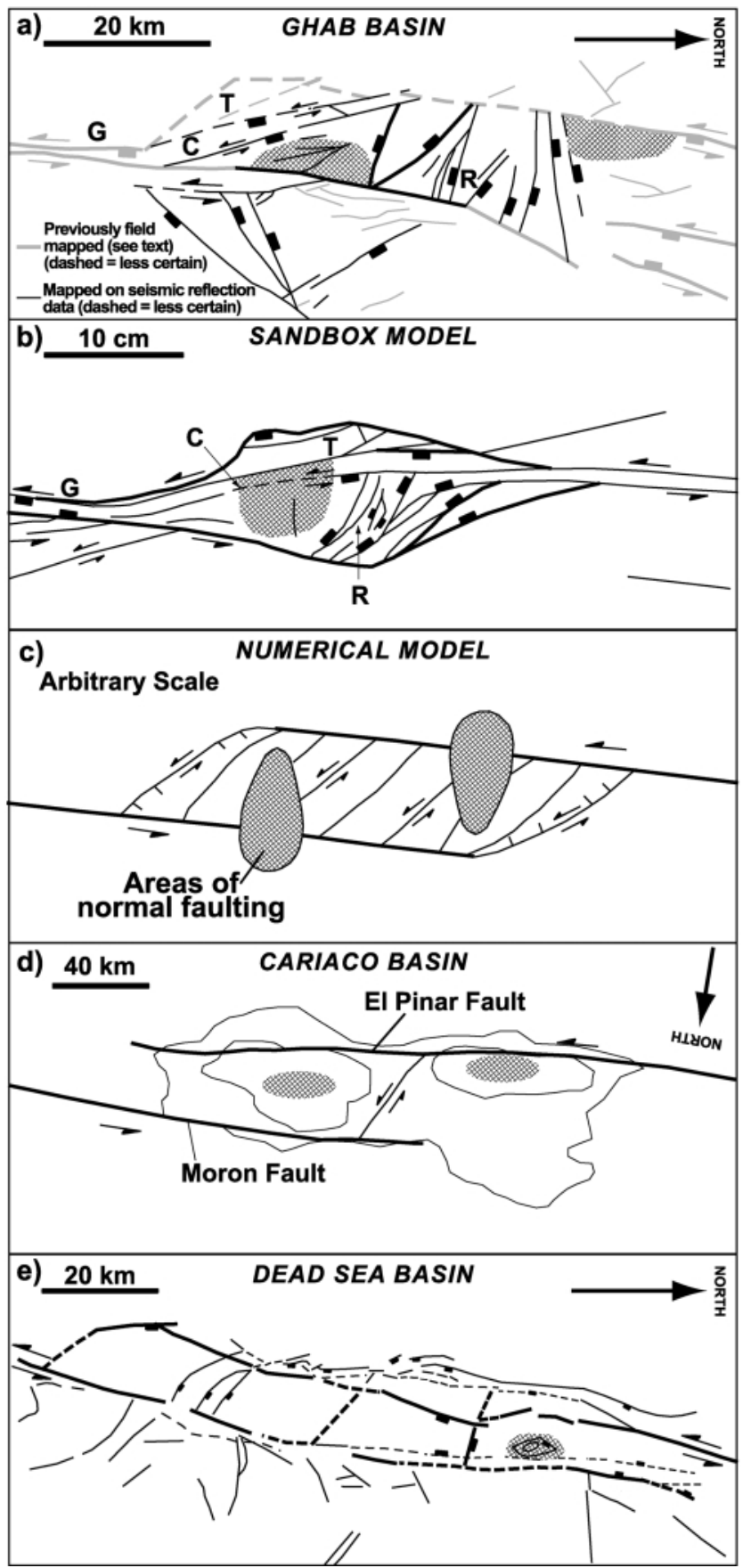

Fig. 6. Comparison of the Ghab basin structure with physical and mathematical models, and real examples of strike-slip basins. Throughout the figure, cross-hatched areas indicate major depocentres and bolder lines indicate faults that are more significant. (a) Fault map in the Ghab basin and immediate surroundings. See Fig. 1 for location. These faults have been mapped either from surface observations and geomorphology (grey lines) (Ponikarov 1966), or from seismic reflection and other interpretations (black lines, this study). Letters G, C, T and R correspond to features also observed in (b). (b) Fault map from a sandbox model of step-over basin, after Dooley \& McClay (1997). (c) Numerical model of a step-over basin from Rodgers (1980). (d) Simplified structure map of the Cariaco basin, Venezuela, from Schubert (1982). (e) Fault map from Dead Sea basin, summarized from several sources (Garfunkel \& Ben-Avraham 1996). 
Ghab basin most of the lateral movement on the Dead Sea fault system is accommodated on the eastern bounding fault of the basin. Some displacement steps over to the western bounding fault farther to the north, and the smaller northern depocentre is slightly asymmetric to the west.

Transverse structures, such as those found in the Ghab basin, are also commonly observed in other strike-slip basins. The Dead Sea basin (Fig. 6e) is bounded by strike-slip faults on which most of the deformation occurs and transverse structures separate smaller sub-basins there (Garfunkel \& Ben-Avraham 1996). Another analogue for the Ghab basin is the Cariaco basin, Venezuela (Fig. 6d), where twin depocentres, asymmetric toward the more active strike-slip and separated by a central sill have developed at a dextral fault step-over (Schubert 1982).

Physical (e.g., sandbox/clay) models of pull-apart basins can provide insight into strike-slip basin evolution by considering simplistic end-member cases that are rare in nature. Of the models Dooley \& McClay (1997), the one with resulting deformation most closely resembling the Ghab basin was a case of an initial $90^{\circ}$ releasing sidestep between the two segments of the strike-slip fault (Fig. 6b). Strong similarities with the Ghab basin include: cross-basin faults (C in Fig. 6) that are active particularly in the early stages of basin evolution, mid-basin ridge ( $\mathrm{R}$ in Fig. 6); strongly terraced sidewalls of basin ( $\mathrm{T}$ in Fig. 6); graben along the principal displacement zone at the basin ends ( $\mathrm{G}$ in Fig. 6).

Rahe et al. (1998) used unequal motion on the 'crustal' blocks on opposite sides of the strike-slip fault in their physical models. The results show asymmetric basins, with increased subsidence toward the moving boundary. Commonly observed in these models are intrabasin highs, early opening accommodated on oblique-slip transverse faults, and switching basin asymmetry along strike (associated with 'master fault' stepover). Again, all these features are observed in the Ghab basin.

Theoretical models for the deformation of a basin under strike-slip conditions were made by Rodgers (1980) and Golke et al. (1994), among others. Rodgers (1980) showed that once the total translation along the bounding strike-slip faults is approximately equal to the separation between the faults, two distinct depocentres begin to form through normal faulting (Fig. 6c). If considered analogous to the Ghab basin (Fig. 6a), this shows that the northern depocentre in the Ghab developed sometime after the initiation of the southern depocentre owing to increasing displacement on the Dead Sea fault system. This explains the smaller size of the northern depocentre. Golke et al. (1994) found that two depocentres developed when initial master fault overlap is close to zero - the $90^{\circ}$ case of Dooley \& McClay (1997). They also saw the formation of asymmetric basins when translation is focused on one of the bounding master faults. Golke et al. (1994) also observed basin migration, in the same sense as that in the Ghab, because of increasing master fault overlap with time.

In summary, we find that many of the second-order structures within the Ghab basin are common to other strike-slip basins. The basin asymmetry seen in the Ghab is probably related to the relative amount of offset on the bounding faults.

\section{Syrian Coastal Ranges}

The topographically prominent Syrian Coastal Ranges, directly west of the Ghab basin (Fig. 1), are clearly related in some way to the evolution of the basin and the Dead Sea fault system. Unfortunately, limited by only surface geological

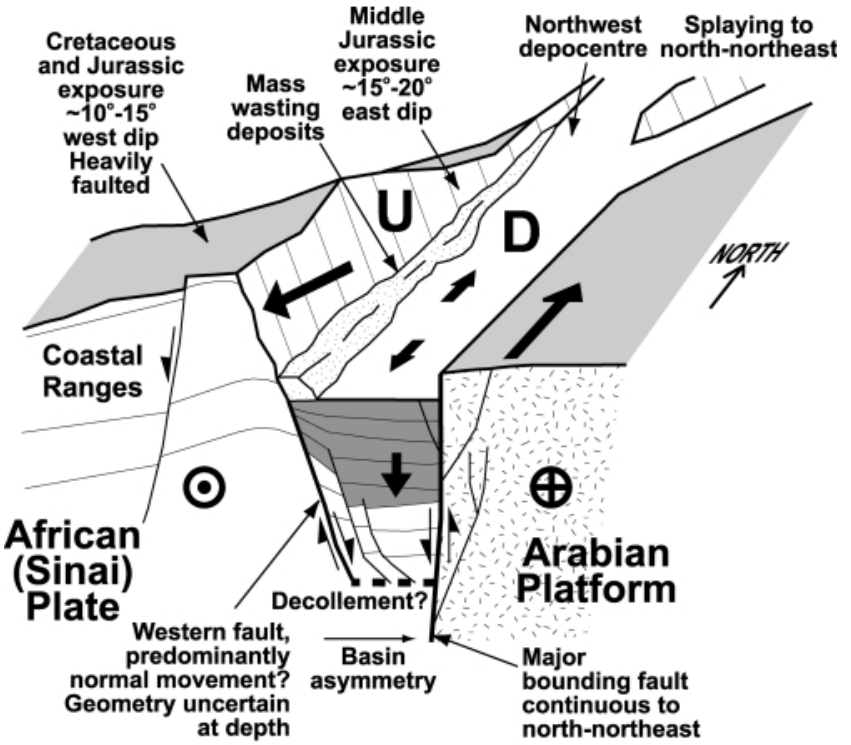

Fig. 7. Highly schematic, vertically exaggerated, three-dimensional representation of the Ghab basin. Large arrows show approximate relative movements; the Coastal Ranges block is depicted uplifting, possibly through rotation, while translating southwards.

evidence, there is significant uncertainty in our knowledge of the uplift history of the Coastal Ranges. Based on stratigraphic relationships we can document that the uplift occurred in at least two phases. The first uplift was sub-parallel, and of similar extent, to the current topography (albeit without the imposition of the Ghab basin), and formed in the Latest Cretaceous and Palaeocene (Ruske 1981). Middle Eocene limestone throughout the studied area (including beneath the Ghab basin) indicates that this initial uplift had largely subsided by Mid-Eocene time.

There is an absence of any Late Eocene-Miocene strata on or around the Coastal Ranges or beneath the Ghab basin, although these strata are found elsewhere in Syria. This strongly suggests that a second stage of uplift started around Late Eocene time, as suggested by Ruske (1981), and most likely is still in progress. The cause of these phases of uplift is interpreted to be regional compression.

Clearly the Coastal Range uplift has been very strongly modified by the propagation of the Dead Sea fault system through NW Syria, and the related formation of the Ghab basin. The Plio-Quaternary Ghab basin formed near what was presumably the crest of the pre-Pliocene Coastal Range uplift. This created the extremely steep scarp on the eastern face of the Coastal Ranges alongside the Ghab basin. Furthermore, the presence of the Dead Sea fault system has caused asymmetry in the uplift (Fig. 1). The Coastal Ranges are topographically and structurally significantly higher directly to the west of the present Dead Sea fault system (Fig. 7). Thus the Coastal Ranges take on the appearance of an uplifted horst, bounded, particularly to the east, by normal faults. PlioQuaternary uplift may, in part, be due to rotation of the Coastal Ranges as the hanging wall of a major fault block. In this scenario, normal faults would be controlling the western margin of the present Ghab basin (Fig. 7), as suggested in the previous section to explain the asymmetry of the Ghab depocentre. Brew (2001) presents further hypotheses and associated mathematical modelling regarding possible causes of the Syrian Coastal Range uplift. 

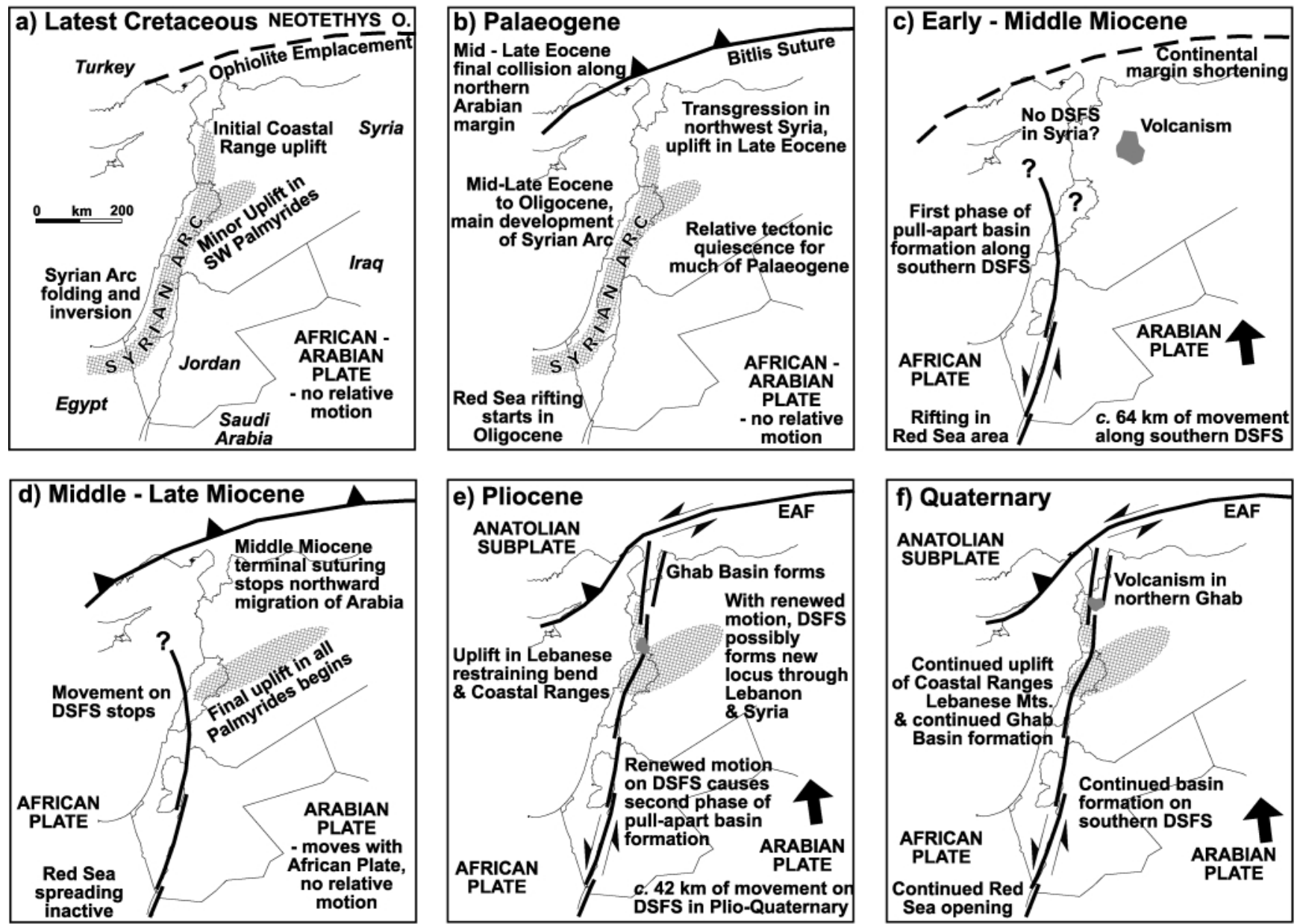

Fig. 8. Maps showing schematic structural evolution of the Dead Sea fault system and Ghab basin in a regional setting. Modern-day geography shown for reference. Bold lines indicate approximate palaeo-plate boundaries, and large arrows indicate approximate motion of Arabia relative to Africa. No attempt is made to illustrate all tectonic events on this map. (EAF is East Anatolian Fault).

\section{Evolution of NW Syria}

\section{Late Cretaceous}

The well-documented Maastrichtian initial uplift of the Syrian Coastal Ranges is coincident with contemporaneous events documented throughout NW Arabia (Fig. 8a). Most notably this time was the first episode in the formation of the 'Syrian Arc'. The Syrian Arc is the swath of folds and structurally inverted faults observed along the Sinai and Levant coasts, sub-parallel to the present shoreline (Fig. 8a). In the original definition (Krenkel 1924) the Arc extended northward towards Turkey, although more recent authors have also included the Palmyride folds in the definition. The formation of the Syrian Arc is dated as a Maastrichtian phenomenon (Guiraud \& Bosworth 1997), although some subtle precursory compression began earlier in the Late Cretaceous (Bartov et al. 1980; Walley 1998). Chaimov et al. (1992) considered the initial folding, uplift, and structural inversion in the southwest Palmyride fold and thrust belt to be part of the Syrian Arc and documented this compression as latest Cretaceous. On a more regional scale, the cessation of extensional tectonics in the Sinjar and Euphrates areas of eastern Syria is well established as a Maastrichtian phenomenon (Brew 2001).

The Maastrichtian was the time of ophiolite emplacement along the northern Arabian margin, particularly in the Baer-
Bassit and Kurd Dagh areas proximal to the present Ghab basin (Robertson et al. 1991). This emplacement occurred as the northern Arabian margin collided with an intra-ocean subduction zone. These collisions can explain the observations of Maastrichtian age compression throughout the northern Arabian platform. Thus, the initial Maastrichtian time uplift of the Coastal Ranges fits well with the previously documented regional plate tectonics. Hence, we interpret the Syrian Coastal Ranges to be part of the Syrian Arc folding, as originally suggested by Walley (1998).

\section{Palaeogene}

The uplift that affected the Coastal Ranges in the latest Cretaceous continued into the Palaeogene but was subdued during the Eocene. Middle Eocene marine deposits were deposited throughout the studied area, with the possible exception of the crest of the Coastal Range uplift that may have remained emerged. As discussed above, the second episode of Coastal Range uplift was post-Mid-Eocene. This corresponds with the second episode of Syrian Arc development (Guiraud \& Bosworth 1997). The Mid-Eocene was also a time of uplift of the Palmyrides (Chaimov et al. 1992) (Fig. 8b), and some minor structural inversion in NE Syria (Brew 2001), resulting in reverse movement on previous normal faults. 
Furthermore, through stratigraphic relationships Dubertret (1975) documented how most of the uplift of the Lebanese mountains occurred during the Late Eocene and Oligocene, a view supported by the more recent work of Walley (1998).

These periods of renewed compression within the northern Arabian platform are clearly related to the Mid-Late Eocene final collision of Eurasia and Arabia along the northern Arabian margin (Hempton 1985). This final obliteration of Neo-Tethys oceanic crust led to the Bitlis suture that still marks the boundary of these plates (Fig. 8b). From Mid-Late Eocene time until the Mid-Miocene, convergence between the Eurasian and Arabian plates was accommodated by continental margin shortening and thickening along this northern margin (Hempton 1987). Hence, the Syrian Coastal Ranges are again shown to be part of the larger Syrian Arc folding coincident with the regional tectonic development.

\section{Miocene}

The first phase of rifting in the Red Sea area saw continental stretching there that probably started in the Oligocene (Hempton 1987). From Early Miocene time onwards the differential motion between northward moving Africa and Arabia began to be accommodated along the newly formed Dead Sea fault system (Fig. 8b, c). Thus c. $64 \mathrm{~km}$ of sinistral motion occurred on the southern Dead Sea fault system during this first phase of movement in Early and Mid-Miocene time (Fig. 8c). Whether this motion was also transmitted to the northern Dead Sea fault system is unclear. Lacking evidence for this pre-Pliocene northern Dead Sea fault system motion we favour a model in which the Miocene motion was translated offshore in southern Lebanon and south of Lebanon. This was first suggested by Chaimov et al. (1990) and requires that the northern Dead Sea fault system only formed in the Pliocene.

In his regional model, Hempton (1987) argues that by Mid-Miocene time the northern margin of Arabia had reached full crustal thickness after shortening and thickening in the Eurasia-Arabia collision. Hempton (1987) suggests that this was therefore the terminal suturing of Eurasia-Arabia, after which Arabia was unable to converge significantly any further on Eurasia, and so spreading in the Red Sea halted. In turn, this led to a cessation of movement along the Dead Sea fault system (Fig. 8d). Thus, in the model of Hempton (1987), the first phase of motion on the Dead Sea fault system came to a close during the Mid-Miocene and the Dead Sea fault system was inactive from around 14.5 Ma until about 4.5 Ma. Other authors suggest a more continuous opening of the Red Sea. For example, Steckler \& ten Brink (1986) show continuous motion of the Dead Sea fault system from around EarlyMid-Miocene time onwards, with a slight reorientation and acceleration in Plio-Quaternary time. We favour Hempton's model because it synthesizes many observations of episodic tectonics and quiescence from deformed zones around the Arabian plate. Interestingly, the time of no fault movement in Hempton's model also approximately corresponds to a period of no volcanic activity in Syria (Mouty et al. 1992).

\section{Pliocene-Recent}

Hempton (1987) goes on to argue that activity on the Dead Sea fault system commenced again in the Early Pliocene (c. $4.5 \mathrm{Ma}$ ) after the re-commencement of Red Sea seafloor spreading. This occurred as the northward Arabia motion was accommodated by the escape of Anatolia along the newly formed North and East Anatolian faults (Fig. 8e). In accordance with this model, we suggest that with the renewed activity and reoriented stress regime, the Dead Sea fault system formed its current path though Syria beginning in Early Pliocene time (Fig. 8e). Besides the Pliocene formation of the Ghab basin, further evidence for Pliocene propagation of the northern Dead Sea fault system comes from offsets in Pliocene basalt and Quaternary fans (Trifonov et al. 1991) together with GPS current motion vectors. Preliminary GPS measurements suggest c. $6 \mathrm{~mm} \mathrm{a}^{-1}$ of relative Africa/Arabia motion in the northern Arabian platform (McClusky et al. 2000), in agreement with field studies (Trifonov et al. 1991). If this motion has been roughly constant, it indicates $c .27 \mathrm{~km}$ of movement in the last $4.5 \mathrm{Ma}$, roughly equivalent to previously suggested totals (Quennell 1984; Trifonov et al. 1991). Furthermore, the focus of volcanic activity in western Syria shifted from the Aleppo plateau to a point along the northern Dead Sea fault system (Fig. 8e) around $5 \mathrm{Ma}$ (Mouty et al., 1992). In this model, the well-established c. $42 \mathrm{~km}$ of post-Miocene Dead Sea fault system motion is accommodated by about $22 \mathrm{~km}$ movement along the northern Dead Sea fault system, and about $20 \mathrm{~km}$ shortening in the Palmyrides (Chaimov et al. 1990) (Fig. 8e).

We suggest that after the northern propagation of the Dead Sea fault system, the Ghab basin formed as a pull-apart basin owing to the complex splaying left step-over in the sinistral fault system. Despite significant relief to the west, surface and subsurface data show that the eastern basin-bounding fault is more active, and this fault is continuous north of the basin as readily seen in topography and seismicity data. This suggests an incomplete transfer of lateral motion from the eastern to the western strands of the Dead Sea fault system across the Ghab basin. Thus, north of the Ghab basin the Dead Sea fault system splays out into a broad zone of deformation with lateral motion distributed amongst several branching faults.

We suggest that during the Pliocene-Recent time the Ghab basin and the northern Dead Sea fault system were superposed on the pre-Pliocene Syrian Coastal Ranges topography. This faulting along the crest of the Coastal Ranges has created the very steep eastern flank of the uplift through normal faulting, and perhaps some rotation of the Coastal Ranges west of the Dead Sea fault system.

\section{Conclusions}

Geomorphology, stratigraphic relationships, and seismicity clearly demonstrate the active deformation of the northern, Syrian segment of the Dead Sea fault system. Sinistral movement at a left-step and splaying of the fault has resulted in the Ghab basin that we interpret to have formed since Early Pliocene time. Cross-basin oblique-slip faults accommodated some initial basin opening, but most subsidence has occurred along the better-defined and apparently more active eastern basin-bounding fault. This has accommodated basin fill thicker (asymmetric) to the east. A northward-shifting depocentre, and the subsequent development of a second depocentre in the Ghab basin, are due to increasing fault overlap with time. These features are commonly observed in other strike-slip basins and models. The basin exhibits two asymmetric depocentres with geometry suggestive of some transformnormal extension. The timing of Ghab basin formation 
supports a model in which the current northern strand of the Dead Sea fault system (in Lebanon and Syria) has only been active since the latest Miocene/earliest Pliocene to Recent.

Uplift of the Syrian Coastal Ranges is probably related to the Syrian Arc and has been episodic since latest Cretaceous time. The first episode of uplift, in the Maastrichtian, was clearly related to plate-wide compression and folding caused by collision along the northern margin of the Arabian plate. Mid-Late Eocene uplift was again contemporaneous with regionally observed folding due to final continent-continent collision along the northern Arabian margin. This uplift is ongoing, and has been strongly influenced by the formation of the Dead Sea fault system, along which basin formation and subsidence to the east was counterbalanced by uplift and tilting of the Coastal Ranges to the west.

Our thanks go to the Syrian Petroleum Company (SPC) for the generous provision of most of the data used in this study. Cornell University, Department of Geological Sciences, acknowledges support of this project by Landmark Graphics Corporation via the Landmark University Grant program. Arco and Conoco provided partial financial assistance to Cornell University. The authors acknowledge the constructive comments of $\mathrm{K}$. Al-Maleh of Damascus University, M. Meghraoui of IPG Strasbourg, and our Cornell colleagues S. Gallow, F. Gomez, T. Jordan, E. Sandvol and especially D. Seber. We also thank M. Miller, Y. Dilek and U. ten Brink for constructive reviews.

\section{References}

Ambraseys, N.N. \& JACKSON, J. A. 1998. Faulting associated with historical and recent earthquakes in the Eastern Mediterranean region. Geophysical Journal International, 133, 390-406.

Bartov, Y., Lewy, Z., Steinitz, G. \& ZAK, I. 1980. Mesozoic and Tertiary Stratigraphy, Paleogeography and Structural History of the Gebel Areif en Naqa Area, Eastern Sinai. Israel Journal of Earth Sciences, 29, 114-139.

Ben-Avraham, Z. 1992. Development of asymmetric basins along continental transform faults. Tectonophysics, 215, 209-220.

Ben-Avraham, Z. \& Zoback, M.D. 1992. Transform-normal extension and asymmetric basins: An alternative to pull-apart models. Geology, 20, 423-426.

Beydoun, Z. 1999. Evolution and development of the Levant (Dead Sea Rift) Transform System: a historical-chronological review of a structural controversy. In: MacNiocaill, C. \& Ryan, P.D. (eds) Continental Tectonics. Geological Society, London. Special Publications, 164, 239-255.

Brew, G. 2001. Tectonic evolution of Syria interpreted from integrated geophysical and geological analysis. PhD Thesis. Cornell University, Ithaca, NY.

Butler, R.W.H., Spencer, S. \& Griffith, H.M. 1997. Transcurrent fault activity on the Dead Sea Transform in Lebanon and its implications for plate tectonics and seismic hazard. Journal of the Geological Society, London, 154, 757-760.

Chaimov, T., Barazangi, M., Al-Saad, D., Sawaf, T. \& Gebran, A. 1990. Crustal shortening in the Palmyride fold belt, Syria, and implications for movement along the Dead Sea fault system. Tectonics, 9, 1369-1386.

Chaimov, T., Barazangi, M., Al-SaAd, D., Sawaf, T. \& Gebran, A. 1992. Mesozoic and Cenozoic deformation inferred from seismic stratigraphy in the southwestern intracontinental Palmyride fold-thrust belt, Syria. Geological Society of America Bulletin, 104, 704-715.

Devyatkin, E.V., Dodonov, A.E., Sharkov, E.V., Zykin, V.S., Simakova, A.N., Kнатів, K. \& NseIr, H. 1997. The El-Ghab Rift Depression in Syria: Its Structure, Stratigraphy, and History of Development. Stratigraphy and Geological Correlation, 5, 362-374.

Dooley, T. \& McClay, K. 1997. Analog modelling of pull-apart basins. American Association of Petroleum Geologists Bulletin, 81, 1804-1826.
Dubertret, L. 1975. Introduction a la Carte Geologique a 1:50 000 du Liban. Notes Memoire Moyen-Orient, 13, 345-403.

Dzhabur, I. 1985. Seismological description of Latakia region of Syria according to borehole and surface observations. Vestnik Moskovskogo Universiteta Geologiya, 40, 90-93.

Garfunkel, Z. \& Ben-Avraham, Z. 1996. The Structure of the Dead Sea basin. Tectonophysics, 266, 155-176.

Golke, M., Cloetingh, S. \& Fuchs, K. 1994. Finite-element modelling of pull-apart basin formation. Tectonophysics, 240, 45-57.

Guiraud, R. \& Bosworth, W. 1997. Senonian basin inversion and rejuvenation of rifting in Africa and Arabia: synthesis and implications to plate-scale tectonics. Tectonophysics, 282, 39-82.

Hempton, M. 1985. Structure and deformation of the Bitlis suture near Lake Hazar, southeastern Turkey. Geological Society of America Bulletin, 96, 233-243.

Hempton, M. 1987. Constraints on Arabian plate motion and extensional history of the Red Sea. Tectonics, 6, 687-705.

Hricko, J. 1988. Geophysical Exploration in Selected Areas of Syrian Arab Republic, Stage Report on Survey in Jisr al Shoghour Area, Unpublished internal report. Strojexport Praha - Geofyzika Brno, Czechoslovakia, Damascus/Brno.

Krenkel, E. 1924. Der Syrische Bogen. Zentralblatt fuer Mineralogie, Geologie und Palaeontologie, 9, 274-281.

Matar, A. \& Mascle, G. 1993. Cinematique de la Faille du Levant au Nord de la Syrie: Analyse Microtectonique du Fosse d'Alghab. Geodinamica Acta, 6 , $153-160$.

McClusky, S. \& Balassanian, S. ET AL. 2000. GPS constraints on plate kinematics and dynamics in the eastern Mediterranean and Caucasus. Journal of Geophysical Research, 105, 5695-5719.

Mouty, M., Delaloye, M., Fontignie, D., Piskin, O. \& Wagner, J. 1992. The volcanic activity in Syria and Lebanon between Jurassic and Actual. Schweizerische Mineralogische und Petrographische Mitteilungen, 72 , 91-105.

Ponikarov, V.P. 1966. The Geology of Syria. Explanatory Notes on the Geological Map of Syria, Scale 1:200 000. Ministry of Industry, Damascus, Syrian Arab Republic

Quennell, A.M. 1959. Tectonics of the Dead Sea Rift Proceedings of the 20th International Geological Congress, Mexico, 385-403.

QuenNell, A.M. 1984. The Western Arabia rift system. In: Dixon, J.E. \& Robertson, A.H.F. (eds) The Geological Evolution of the Eastern Mediterranean. Geological Society, London. Special Publications, 17, 775-788.

Rahe, B., Ferrill, D.A. \& Morris, A.P. 1998. Physical analog modeling of pull-apart basin evolution. Tectonophysics, 285, 21-40.

Robertson, A.H.F., Clift, P.D., Degnan, P.J. \& Jones, G. 1991. Palaeogeographic and palaeotectonic evolution of the Eastern Mediterranean Neotethys. Palaeogeography, Palaeoclimatology, Palaeoecology, 87, 289343.

RodGers, D.A. 1980. Analysis of pull-apart basin development produced by en echelon strike-slip faults. In: Ballance, P.F. \& Reading, H.G. (eds) Sedimentation in Oblique-slip Mobile Zones. International Society of Sedimentologists Special Publications, 4, 27-41.

Ruske, R. 1981. Geologie des syrischen Kustengebirges. VEG Deutscher Verlag fur Grundstoffindustrie, Leipzig.

Schubert, C. 1982. Origin of Cariaco basin, South Caribbean Sea. Marine Geology, 47, 345-360.

Seber, D., Barazangi, M., Chaimov, T., Al-SaAd, D., Sawaf, T. \& Khaddour, M. 1993. Upper crustal velocity structure and basement morphology beneath the intracontinental Palmyride fold-thrust belt and north Arabian platform in Syria. Geophysical Journal International, 113, 752-766.

SteCKLER, M. \& TEN BRINK, U. 1986. Lithospheric strength variations as a control on new plate boundaries: examples from the northern Red Sea. Earth and Planetary Science Letters, 79, 120-132.

Trifonov, V.G., Trubikhin, V.M., Adzhamyan, Z., Dzhallad, S., El-Khair, Y.\& Ayed, K. 1991. Levant fault zone in northwest Syria. Geotectonics, 25, $145-154$.

WALLEY, C. 1998. Some outstanding issues in the geology of Lebanon and their importance in the tectonic evolution of the Levantine region. Tectonophysics, 298, 37-62. 